\title{
The genomic stability of induced pluripotent stem cells
}

\author{
Zhao Chen, Tongbiao Zhao, Yang Xu ${ }^{\bowtie}$ \\ Division of Biological Sciences, University of California, San Diego, La Jolla, CA 92093-0322, USA \\ $\triangle$ Correspondence: yangxu@ucsd.edu \\ Received March 15, 2012 Accepted March 21, 2012
}

\begin{abstract}
With their capability to undergo unlimited self-renewal and to differentiate into all cell types in the body, induced pluripotent stem cells (iPSCs), reprogrammed from somatic cells of human patients with defined factors, hold promise for regenerative medicine because they can provide a renewable source of autologous cells for cell therapy without the concern for immune rejection. In addition, iPSCs provide a unique opportunity to model human diseases with complex genetic traits, and a panel of human diseases have been successfully modeled in vitro by patient-specific iPSCs. Despite these progresses, recent studies have raised the concern for genetic and epigenetic abnormalities of iPSCs that could contribute to the immunogenicity of some cells differentiated from iPSCs. The oncogenic potential of iPSCs is further underscored by the findings that the critical tumor suppressor p53, known as the guardian of the genome, suppresses induced pluripotency. Therefore, the clinic application of iPSCs will require the optimization of the reprogramming technology to minimize the genetic and epigenetic abnormalities associated with induced pluripotency.
\end{abstract}

KEYWORDS induced pluripotent stem cells, reprogramming, genetic and epigenetic abnormalities

\section{INTRODUCTION}

The successful establishment of human embryonic stem cells (hESCs) could provide a renewable source of various cell types for human cell therapy (Thomson et al., 1998). Significant progress has been made in establishing conditions to differentiate hESCs into various lineages of therapeutically valuable cells ( $\mathrm{Fu}$ and $\mathrm{Xu}, 2011$ ). In addition, the ongoing clinical trial of hESC-based therapy of spinal cord injury and macular degeneration has further improved the feasibility of hESC-based cell therapy. While highly promising, there are several challenges facing hESC-based therapy, such as the ethical issues of destroying the human embryo and the immune rejection of the allogenic hESC-derived cells by the recipients (Fu and $\mathrm{Xu}, 2011)$. These challenges are overcome by the groundbreaking discovery of induced pluripotent stem cells (iPSCs) reprogrammed from somatic cells with defined factors (Oct4, Sox2, KIf4 and c-Myc) (Takahashi and Yamanaka, 2006). Soon after the initial discovery, scientists have been able to reprogram somatic cells including terminally differentiated cells from many species including human into iPSCs (Takahashi et al., 2007; Yu et al., 2007; Aasen et al., 2008; Aoi et al., 2008; Eminli et al., 2008; Hanna et al., 2008; Kim et al., 2008; Liu et al., 2008; Maherali et al., 2008; Park et al., 2008b; Stadtfeld et al., 2008; Eminli et al., 2009; Esteban et al., 2009; Li et al., 2009b; Utikal et al., 2009a; Wu et al., 2010). To conclusively demonstrate that iPSCs are equivalent to embryonic stem cells (ESCs) in the context of pluripotency, three independent groups successfully generated the iPSC-mice using tetraploid complementation (Boland et al., 2009; Kang et al., 2009; Zhao et al., 2009). Therefore, patient-specific iPSCs hold great potential to bypass the ethical controversies and immune rejection problem associated with $\mathrm{hESCs}$ in regenerative medicine.

\section{IPSCS IN DISEASE MODELING}

Mouse models for human diseases have been a powerful tool to help us understand the mechanism of pathogenesis in human diseases (Bedell et al., 1997a, 1997b). However, mouse models have limitations in studying human diseases due to the species-specific differences and inaccurate recapitulation of human disease phenotypes. In support of this 
notion, most drugs that have worked well in mouse models fail in human clinical trials (Tiscornia et al., 2011). hESCs genetically modified with genetic mutations linked to human diseases provide an unlimited resource of various cell types affected in human diseases for mechanistic studies and drug discovery, thus opening up a new area of human disease modeling (Song et al., 2010). However, hESCs cannot be used to model human diseases with complex or unknown genetic traits, a challenge that can be overcome by iPSCs. In this context, iPSC technology has been used to model a large panel of human diseases including spinal muscular atrophy (Ebert et al., 2009), amyotrophic lateral sclerosis (Dimos et al., 2008), familial dysautonomia (Lee et al., 2009), Long QT syndrome (Moretti et al., 2010; Itzhaki et al., 2011), LEOPARD syndrome (Carvajal-Vergara et al., 2010), dyskeratosis congenital (Agarwal et al., 2010), Rett's syndrome (Marchetto et al., 2010), Timothy syndrome (Yazawa et al., 2011), schizophrenia (Brennand et al., 2011), Parkinson's disease (PD) (Nguyen et al., 2011), Hutchinson-Gilford progeria syndrome (Liu et al., 2011; Zhang et al., 2011), Alzheimer's disease (AD) (Israel et al., 2012) as well as adenosine deaminase deficiency-related severe combined immunodeficiency, Shwachman-Bodian-Diamond syndrome, Gaucher disease type III, Duchenne and Becker muscular dystrophy, Huntington disease, juvenile-onset, type 1 diabetes mellitus, Down syndrome/trisomy 21 and the carrier state of Lesch-Nyhan syndrome (Park et al., 2008a). In these human diseases such as type I diabetes, AD and PD, the limited access to the affected tissues and the inability to grow the affected cells in culture have hindered the development of effective treatment for these devastating diseases. The generation of disease-specific iPSCs will greatly facilitate the mechanistic studies and the development of therapeutic interventions.

\section{REPROGRAMMING FACTORS: PLURIPOTENCY AND TUMORIGENICITY}

The reprogramming factors include Oct4, Sox2, Nanog, Klf4, c-Myc and Lin28 (Takahashi et al., 2007; Yu et al., 2007). Oct4, Sox2 and Nanog are highly expressed in pluripotent lineages of the early embryo and play important roles in maintaining pluripotency of ESCs (Pesce and Schöler, 2001; Avilion et al., 2003; Chambers et al., 2003; Mitsui et al., 2003). The Oct4 protein levels are tightly regulated for the maintenance of pluripotent stem cells (Niwa et al., 2000). Sox2 can heterodimerize with Oct4 and is important for Oct4 dependent gene expression to stabilize the pluripotent state of ESCs (Masui et al., 2007). Genome-wide location analyses have shown that Oct4, Sox2 and Nanog all bind to their own promoters as well as each other's promoters, indicating a complex autoregulatory circuitry (Boyer et al., 2005; Loh et al., 2006). Klf4 and c-Myc are involved in a wide range of cellular processes, including proliferation, differentiation and cell growth (Dang et al., 2000; Dang et al., 2006). A possible role of Klf4 and c-Myc in reprogramming is to convert somatic cells into highly proliferative state associated with pluripotent stem cells (Yamanaka, 2007). Lin28 is shown to block the processing of the let-7 family miRNAs in ESCs that induces the differentiation (Newman et al., 2008; Viswanathan et al., 2008). Therefore, Lin28 may facilitate the reprogramming process by blocking the miRNA-mediated differentiation.

Mice generated with iPSCs reprogrammed by retroviral vectors developed malignant tumors, raising the concerns of the cancer risk of iPSCs (Okita et al., 2007; Tong et al., 2011). The spontaneous reactivation of C-myc could play an important role in inducing tumorigenesis. Although new methods have been developed to generate iPSCs in the absence of $\mathrm{C}$-myc or without any random integration of the reprogramming factors, concerns for cancer risk remain because the other reprogramming factors also have oncogenic potential. For example, Oct4 has been implicated in tumor formation (Gidekel et al., 2003; Hochedlinger et al., 2005; Levings et al., 2009). Sox 2 is overexpressed in many human cancers and is a lineage-specific oncogene (Bass et al., 2009). Klf4 functions as an oncogene in a context dependent manner (Rowland and Peeper, 2006). Nanog is overexpressed in many human cancers and might play a role in metastasis (Hart et al., 2005; Piestun et al., 2006; Chiou et al., 2010). Recent studies have also suggested that Lin28 can promote the cellular transformation and is associated with malignancies in multiple tumor types (Viswanathan et al., 2009; Peng et al., 2010).

To reduce the oncogenic potential, significant progress has been achieved by developing small molecule compounds that can improve the reprogramming efficiency or replace the reprogramming factors. For example, the reprogramming efficiency was significantly enhanced by small molecule compounds that are epigenetic modifiers including DNA methyltransferase inhibitor, histone methyltransferase inhibitor, histone demethylase inhibitor, histone deacetylase inhibitor, lysine-specific demethylase 1 inhibitor, and TGF- $\beta$ pathway antagonist, MAPK/ERK inhibitor, PDK1 kinase activator, GSK3 inhibitor as well as vitamin C (Huangfu et al., 2008; Shi et al., 2008; Ichida et al., 2009; Li et al., 2009c; Lin et al., 2009; Esteban et al., 2010; Zhu et al., 2010; Li et al., 2011; Yuan et al., 2011). In addition, the reprogramming efficiency of the progenitor cells such as the hematopoietic stem cells and neural stem cells is greatly increased, while the requirement for the reprogramming factors is reduced, suggesting that the oncogenic potential of the induced pluripotency could be reduced when using the progenitor cells (Eminli et al., 2009). While promising, the oncogenic potential of iPSCs reprogrammed with these approaches remains to be evaluated.

\section{P53 AND GENOMIC INSTABILITY OF IPSCS}

As a tumor suppressor, p53 is critical to maintain genomic 
stability in mammalian cells (Zhao and Xu, 2010). In response to DNA damage, p53 is activated to initiate cell cycle arrest and DNA damage repair process. Catastrophic damage will trigger the p53 to eliminate the damaged cell via p53 dependent senescence or apoptosis pathways (Ko and Prives, 1996). As the guardian of the genome, p53 plays an important role in maintaining the genetic stability in response to oncogenic stress. Consistent with the oncogenic potential of iPSCs, a series of studies have shown that p53 significantly suppresses the induced reprogramming (Zhao et al., 2008; Banito et al., 2009; Hong et al., 2009; Kawamura et al., 2009; Li et al., 2009a; Utikal et al., 2009b). In further support of this role of $\mathrm{p} 53$, published studies have shown that $\mathrm{p} 53$ maintains the genetic stability of the self-renewing embryonic stem (ES) cells by suppressing the expression of Nanog, leading to the differentiation of DNA-damaged ES cells (Lin et al., 2005). Therefore, the inactivation of p53 appears to be required for successful reprogramming, raising the concerns about the genetic instability of iPSCs and derivatives (Zhao and $X u, 2010$ ). In support of this notion, the reprogramming is associated with DNA damage and the efficiency enhanced by p53 inhibition is directly proportional to the accelerated proliferation rate with increased DNA damage (Hanna et al., 2009; Lake et al., 2012), leading to iPSCs with persistent DNA damage and chromosomal aberrations (Marión et al., 2009). In addition, the p53 mutation has also been shown to augment the malignant potential of the reprogrammed cells (Sarig et al., 2010). In summary, these studies indicate that functional p53 is critical to ensure genetic stability during the reprogramming process. Instead of silencing p53 to increase the reprogramming efficiency at the expense of genetic stability, a recent study has demonstrated that the deficiency of Puma and p21 can increase the reprogramming efficiency to the same level as p53 deficiency, while prevent the accumulation of DNA damage during reprogramming (Lake et al., 2012). In this context, Puma-deficiency promotes the senescence pathway to eliminate the reprogramming cells with increased DNA damage. Therefore, this finding indicates the feasibility to increase the reprogramming efficiency without sacrificing the genomic integrity.

\section{EPIGENETIC, GENETIC ABNORMALITY AND IMMUNOGENICITY OF IPSCS}

The reprogramming of somatic cells into iPSCs involves the re-establishment of ESC-like epigenetics. Although the majority of the epigenome of iPSCs are similar to that of ESCs, there remains a significant difference including the aberrant silencing of imprinted genes and DNA methylation patterns such as the residual epigenetic memories from somatic cells of origin (Pick et al., 2009; Kim et al., 2010; Polo et al., 2010; Stadtfeld et al., 2010; Lister et al., 2011). Furthermore, some epigenetic abnormalities of iPSCs are common among iPSCs from different origins of somatic cells, indicating that some of the epigenetic abnormalities of the iPSCs are induced during the reprogramming (Lister et al., 2011).

In addition to the epigenetic abnormalities, recent studies have identified genomic abnormalities such as chromosomal aneuploidy and translocations, megabase-scale duplications and deletions, and point mutations in iPSCs (Mayshar et al., 2010; Gore et al., 2011; Hussein et al., 2011; Laurent et al., 2011). Gore and colleagues have identified that point mutations have been accumulated particularly in oncogenic pathways in otherwise karyotypically normal human iPSCs (Gore et al., 2011). Hussein and colleagues have reported that early-passage human iPSCs contained increased copy number variants (CNVs) compared to intermediate-passage iPSCs cells or ESCs (Hussein et al., 2011). Some of these aberrations show a high incidence of chromosome 12 duplications, resulting in upregulation of Nanog and Gdf3, which may facilitate the adaptation process during reprogramming (Mayshar et al., 2010). Laurent and colleagues found increased subchromosomal CNVs in pluripotent cell samples with the enriched CNVs located in specific genomic regions (Laurent et al., 2011). They also found increased numbers of deletions in human iPSCs samples associated with tumor-suppressor genes, whereas duplications of oncogenes are found in iPSCs that have been cultured for extended time (Laurent et al., 2011).

ESCs can undergo unlimited self-renewal and retain the pluripotency to differentiate into all cell types in the body, and thus hold great promise for cell replacement therapy. However, one major obstacle is that the cells derived from established human ESC lines are allogeneic and immune rejected by the recipients. The patient-specific iPSCs could mitigate this problem as a renewable source of autologous cells for human therapy. Although it has been widely assumed that the autologous cells derived from patient-specific iPSCs are immune tolerant in that patient, recent studies have shown that the derivatives of mouse iPSCs can be immunogenic in syngeneic recipients (Zhao et al., 2011). Global gene expression analysis of teratomas formed by B6 ESCs and iPSCs revealed a number of genes overexpressed in teratomas derived from iPSCs, and several of these genes' products directly contributed to the immunogenicity of the B6 iPSCs-derived cells in B6 mice in a T cell dependent manner. While remained to be determined, the aberrant expression of these minor antigens could be due to the epigenetic difference between iPSCs and ESCs. In addition, the contribution of genetic mutations to the immunogenicity of iPSC derivatives remains to be evaluated.

\section{CONCLUSION REMARKS}

The groundbreaking discovery of iPSCs has reshaped the scientific and political landscapes of stem cell biology. It provides an unprecedented opportunity to model human disease and re-examine some of the basic biology such as develop- 
ment and differentiation. The potential of iPSCs in drug discovery is tremendous. However, recent findings of epigenetic and genetic abnormalities in iPSCs raise the safety concerns of iPSCs in human cell therapy. In addition, the cancer risk associated with induced pluripotency must be vigorously addressed before any clinical application of iPSCs.

\section{ACKNOWLEDGEMENTS}

This work was supported by a grant from California Institute for Regenerative Medicine (ET-01277) to Y. X.

\section{REFERENCES}

Aasen, T., Raya, A., Barrero, M.J., Garreta, E., Consiglio, A., Gonzalez, F., Vassena, R., Bilić, J., Pekarik, V., Tiscornia, G., et al. (2008). Efficient and rapid generation of induced pluripotent stem cells from human keratinocytes. Nat Biotechnol 26, 1276-1284.

Agarwal, S., Loh, Y.H., McLoughlin, E.M., Huang, J., Park, I.H., Miller, J.D., Huo, H., Okuka, M., Dos Reis, R.M., Loewer, S., et al. (2010). Telomere elongation in induced pluripotent stem cells from dyskeratosis congenita patients. Nature 464, 292-296.

Aoi, T., Yae, K., Nakagawa, M., Ichisaka, T., Okita, K., Takahashi, K., Chiba, T., and Yamanaka, S. (2008). Generation of pluripotent stem cells from adult mouse liver and stomach cells. Science 321, 699-702.

Avilion, A.A., Nicolis, S.K., Pevny, L.H., Perez, L., Vivian, N., and Lovell-Badge, R. (2003). Multipotent cell lineages in early mouse development depend on SOX2 function. Genes Dev 17, 126-140.

Banito, A., Rashid, S.T., Acosta, J.C., Li, S., Pereira, C.F., Geti, I., Pinho, S., Silva, J.C., Azuara, V., Walsh, M., et al. (2009). Senescence impairs successful reprogramming to pluripotent stem cells. Genes Dev 23, 2134-2139.

Bass, A.J., Watanabe, H., Mermel, C.H., Yu, S., Perner, S., Verhaak, R.G., Kim, S.Y., Wardwell, L., Tamayo, P., Gat-Viks, I., et al. (2009). SOX2 is an amplified lineage-survival oncogene in lung and esophageal squamous cell carcinomas. Nat Genet 41, 1238-1242.

Bedell, M.A., Jenkins, N.A., and Copeland, N.G. (1997a). Mouse models of human disease. Part I: techniques and resources for genetic analysis in mice. Genes Dev 11, 1-10.

Bedell, M.A., Largaespada, D.A., Jenkins, N.A., and Copeland, N.G. (1997b). Mouse models of human disease. Part II: recent progress and future directions. Genes Dev 11, 11-43.

Boland, M.J., Hazen, J.L., Nazor, K.L., Rodriguez, A.R., Gifford, W., Martin, G., Kupriyanov, S., and Baldwin, K.K. (2009). Adult mice generated from induced pluripotent stem cells. Nature 461, 91-94.

Boyer, L.A., Lee, T.I., Cole, M.F., Johnstone, S.E., Levine, S.S., Zucker, J.P., Guenther, M.G., Kumar, R.M., Murray, H.L., Jenner, R.G., et al. (2005). Core transcriptional regulatory circuitry in human embryonic stem cells. Cell 122, 947-956.

Brennand, K.J., Simone, A., Jou, J., Gelboin-Burkhart, C., Tran, N., Sangar, S., Li, Y., Mu, Y., Chen, G., Yu, D., et al. (2011). Modelling schizophrenia using human induced pluripotent stem cells. Nature 473, 221-225.

Carvajal-Vergara, X., Sevilla, A., D'Souza, S.L., Ang, Y.S., Schaniel, C., Lee, D.F., Yang, L., Kaplan, A.D., Adler, E.D., Rozov, R., et al.
(2010). Patient-specific induced pluripotent stem-cell-derived models of LEOPARD syndrome. Nature 465, 808-812.

Chambers, I., Colby, D., Robertson, M., Nichols, J., Lee, S., Tweedie, S., and Smith, A. (2003). Functional expression cloning of Nanog, a pluripotency sustaining factor in embryonic stem cells. Cell 113, 643-655.

Chiou, S.H., Wang, M.L., Chou, Y.T., Chen, C.J., Hong, C.F., Hsieh, W.J., Chang, H.T., Chen, Y.S., Lin, T.W., Hsu, H.S., et al. (2010). Coexpression of Oct4 and Nanog enhances malignancy in lung adenocarcinoma by inducing cancer stem cell-like properties and epithelial-mesenchymal transdifferentiation. Cancer Res 70, 10433-10444.

Dang, C.V., O'Donnell, K.A., Zeller, K.I., Nguyen, T., Osthus, R.C., and $\mathrm{Li}, \mathrm{F}$. (2006). The c-Myc target gene network. Semin Cancer Biol 16, 253-264.

Dang, D.T., Pevsner, J., and Yang, V.W. (2000). The biology of the mammalian Krüppel-like family of transcription factors. Int J Biochem Cell Biol 32, 1103-1121.

Dimos, J.T., Rodolfa, K.T., Niakan, K.K., Weisenthal, L.M., Mitsumoto, H., Chung, W., Croft, G.F., Saphier, G., Leibel, R., Goland, R., et al. (2008). Induced pluripotent stem cells generated from patients with ALS can be differentiated into motor neurons. Science 321 , 1218-1221.

Ebert, A.D., Yu, J., Rose, F.F. Jr, Mattis, V.B., Lorson, C.L., Thomson, J.A., and Svendsen, C.N. (2009). Induced pluripotent stem cells from a spinal muscular atrophy patient. Nature 457, 277-280.

Eminli, S., Foudi, A., Stadtfeld, M., Maherali, N., Ahfeldt, T., Mostoslavsky, G., Hock, H., and Hochedlinger, K. (2009). Differentiation stage determines potential of hematopoietic cells for reprogramming into induced pluripotent stem cells. Nat Genet 41, 968-976.

Eminli, S., Utikal, J., Arnold, K., Jaenisch, R., and Hochedlinger, K. (2008). Reprogramming of neural progenitor cells into induced pluripotent stem cells in the absence of exogenous Sox2 expression. Stem Cells 26, 2467-2474.

Esteban, M.A., Wang, T., Qin, B., Yang, J., Qin, D., Cai, J., Li, W., Weng, Z., Chen, J., Ni, S., et al. (2010). Vitamin C enhances the generation of mouse and human induced pluripotent stem cells. Cell Stem Cell 6, 71-79.

Esteban, M.A., Xu, J., Yang, J., Peng, M., Qin, D., Li, W., Jiang, Z., Chen, J., Deng, K., Zhong, M., et al. (2009). Generation of induced pluripotent stem cell lines from Tibetan miniature pig. J Biol Chem 284, 17634-17640.

Fu, X., and Xu, Y. (2011). Self-renewal and scalability of human embryonic stem cells for human therapy. Regen Med 6, 327-334.

Gidekel, S., Pizov, G., Bergman, Y., and Pikarsky, E. (2003). Oct-3/4 is a dose-dependent oncogenic fate determinant. Cancer Cell 4 , 361-370.

Gore, A., Li, Z., Fung, H.L., Young, J.E., Agarwal, S., Antosiewicz-Bourget, J., Canto, I., Giorgetti, A., Israel, M.A., Kiskinis, E., et al. (2011). Somatic coding mutations in human induced pluripotent stem cells. Nature 471, 63-67.

Hanna, J., Markoulaki, S., Schorderet, P., Carey, B.W., Beard, C., Wernig, M., Creyghton, M.P., Steine, E.J., Cassady, J.P., Foreman, R., et al. (2008). Direct reprogramming of terminally differentiated mature B lymphocytes to pluripotency. Cell 133, 250-264.

Hanna, J., Saha, K., Pando, B., van Zon, J., Lengner, C.J., Creyghton, 
M.P., van Oudenaarden, A., and Jaenisch, R. (2009). Direct cell reprogramming is a stochastic process amenable to acceleration. Nature 462, 595-601.

Hart, A.H., Hartley, L., Parker, K., Ibrahim, M., Looijenga, L.H., Pauchnik, M., Chow, C.W., and Robb, L. (2005). The pluripotency homeobox gene NANOG is expressed in human germ cell tumors. Cancer 104, 2092-2098.

Hochedlinger, K., Yamada, Y., Beard, C., and Jaenisch, R. (2005). Ectopic expression of Oct-4 blocks progenitor-cell differentiation and causes dysplasia in epithelial tissues. Cell 121, 465-477.

Hong, H., Takahashi, K., Ichisaka, T., Aoi, T., Kanagawa, O., Nakagawa, M., Okita, K., and Yamanaka, S. (2009). Suppression of induced pluripotent stem cell generation by the p53-p21 pathway. Nature 460, 1132-1135.

Huangfu, D., Maehr, R., Guo, W., Eijkelenboom, A., Snitow, M., Chen, A.E., and Melton, D.A. (2008). Induction of pluripotent stem cells by defined factors is greatly improved by small-molecule compounds. Nat Biotechnol 26, 795-797.

Hussein, S.M., Batada, N.N., Vuoristo, S., Ching, R.W., Autio, R., Närvä, E., Ng, S., Sourour, M., Hämäläinen, R., Olsson, C., et al. (2011). Copy number variation and selection during reprogramming to pluripotency. Nature 471, 58-62.

Ichida, J.K., Blanchard, J., Lam, K., Son, E.Y., Chung, J.E., Egli, D., Loh, K.M., Carter, A.C., Di Giorgio, F.P., Koszka, K., et al. (2009). A small-molecule inhibitor of tgf-Beta signaling replaces sox2 in reprogramming by inducing nanog. Cell Stem Cell 5, 491-503.

Israel, M.A., Yuan, S.H., Bardy, C., Reyna, S.M., Mu, Y., Herrera, C., Hefferan, M.P., Van Gorp, S., Nazor, K.L., Boscolo, F.S., et al. (2012). Probing sporadic and familial Alzheimer's disease using induced pluripotent stem cells. Nature 482, 216-220.

Itzhaki, I., Maizels, L., Huber, I., Zwi-Dantsis, L., Caspi, O., Winterstern, A., Feldman, O., Gepstein, A., Arbel, G., Hammerman, H., et al. (2011). Modelling the long QT syndrome with induced pluripotent stem cells. Nature 471, 225-229.

Kang, L., Wang, J., Zhang, Y., Kou, Z., and Gao, S. (2009). iPS cells can support full-term development of tetraploid blastocyst-complemented embryos. Cell Stem Cell 5, 135-138.

Kawamura, T., Suzuki, J., Wang, Y.V., Menendez, S., Morera, L.B., Raya, A., Wahl, G.M., and Belmonte, J.C. (2009). Linking the p53 tumour suppressor pathway to somatic cell reprogramming. Nature 460, 1140-1144.

Kim, J.B., Zaehres, H., Wu, G., Gentile, L., Ko, K., Sebastiano, V., Araúzo-Bravo, M.J., Ruau, D., Han, D.W., Zenke, M., et al. (2008) Pluripotent stem cells induced from adult neural stem cells by reprogramming with two factors. Nature 454, 646-650.

Kim, K., Doi, A., Wen, B., Ng, K., Zhao, R., Cahan, P., Kim, J., Aryee, M.J., Ji, H., Ehrlich, L.I., et al. (2010). Epigenetic memory in induced pluripotent stem cells. Nature 467, 285-290.

Ko, L.J., and Prives, C. (1996). p53: puzzle and paradigm. Genes Dev 10, 1054-1072.

Lake, B.B., Fink, J., Klemetsaune, L., Fu, X., Jeffers, J.R., Zambetti, G.P., and Xu, Y. (2012). Context-dependent enhancement of induced pluripotent stem cell reprogramming by silencing Puma. Stem Cells 2012 Feb 6. doi: 10.1002/stem.1054. [Epub ahead of print]

Laurent, L.C., Ulitsky, I., Slavin, I., Tran, H., Schork, A., Morey, R., Lynch, C., Harness, J.V., Lee, S., Barrero, M.J., et al. (2011). Dynamic changes in the copy number of pluripotency and cell proliferation genes in human ESCs and iPSCs during reprogramming and time in culture. Cell Stem Cell 8, 106-118.

Lee, G., Papapetrou, E.P., Kim, H., Chambers, S.M., Tomishima, M.J., Fasano, C.A., Ganat, Y.M., Menon, J., Shimizu, F., Viale, A., et al. (2009). Modelling pathogenesis and treatment of familial dysautonomia using patient-specific iPSCs. Nature 461, 402-406.

Levings, P.P., McGarry, S.V., Currie, T.P., Nickerson, D.M., McClellan, S., Ghivizzani, S.C., Steindler, D.A., and Gibbs, C.P. (2009). Expression of an exogenous human Oct-4 promoter identifies tumor-initiating cells in osteosarcoma. Cancer Res 69, 5648-5655.

Li, H., Collado, M., Villasante, A., Strati, K., Ortega, S., Canamero, M., Blasco, M.A., and Serrano, M. (2009a). The Ink4/Arf locus is a barrier for iPS cell reprogramming. Nature 460, 1136-1139.

Li, W., Wei, W., Zhu, S., Zhu, J., Shi, Y., Lin, T., Hao, E., Hayek, A., Deng, H., and Ding, S. (2009b). Generation of rat and human induced pluripotent stem cells by combining genetic reprogramming and chemical inhibitors. Cell Stem Cell 4, 16-19.

Li, W., Zhou, H., Abujarour, R., Zhu, S., Young Joo, J., Lin, T., Hao, E., Schöler, H.R., Hayek, A., and Ding, S. (2009c). Generation of human-induced pluripotent stem cells in the absence of exogenous Sox2. Stem Cells 27, 2992-3000.

Li, Y., Zhang, Q., Yin, X., Yang, W., Du, Y., Hou, P., Ge, J., Liu, C., Zhang, W., Zhang, X., et al. (2011). Generation of iPSCs from mouse fibroblasts with a single gene, Oct4, and small molecules. Cell Res 21, 196-204.

Lin, T., Ambasudhan, R., Yuan, X., Li, W., Hilcove, S., Abujarour, R., Lin, X., Hahm, H.S., Hao, E., Hayek, A., et al. (2009). A chemical platform for improved induction of human iPSCs. Nat Methods 6 , 805-808.

Lin, T., Chao, C., Saito, S., Mazur, S.J., Murphy, M.E., Appella, E., and $\mathrm{Xu}, \mathrm{Y}$. (2005). p53 induces differentiation of mouse embryonic stem cells by suppressing Nanog expression. Nat Cell Biol 7, 165-171.

Lister, R., Pelizzola, M., Kida, Y.S., Hawkins, R.D., Nery, J.R., Hon, G., Antosiewicz-Bourget, J., O'Malley, R., Castanon, R., Klugman, $S$., et al. (2011). Hotspots of aberrant epigenomic reprogramming in human induced pluripotent stem cells. Nature 471, 68-73.

Liu, G.H., Barkho, B.Z., Ruiz, S., Diep, D., Qu, J., Yang, S.L., Panopoulos, A.D., Suzuki, K., Kurian, L., Walsh, C., et al. (2011). Recapitulation of premature ageing with iPSCs from Hutchinson-Gilford progeria syndrome. Nature 472, 221-225.

Liu, H., Zhu, F., Yong, J., Zhang, P., Hou, P., Li, H., Jiang, W., Cai, J., Liu, M., Cui, K., et al. (2008). Generation of induced pluripotent stem cells from adult rhesus monkey fibroblasts. Cell Stem Cell 3, 587-590.

Loh, Y.H., Wu, Q., Chew, J.L., Vega, V.B., Zhang, W., Chen, X., Bourque, G., George, J., Leong, B., Liu, J., et al. (2006). The Oct4 and Nanog transcription network regulates pluripotency in mouse embryonic stem cells. Nat Genet 38, 431-440.

Maherali, N., Ahfeldt, T., Rigamonti, A., Utikal, J., Cowan, C., and Hochedlinger, K. (2008). A high-efficiency system for the generation and study of human induced pluripotent stem cells. Cell Stem Cell 3, 340-345.

Marchetto, M.C., Carromeu, C., Acab, A., Yu, D., Yeo, G.W., Mu, Y., Chen, G., Gage, F.H., and Muotri, A.R. (2010). A model for neural development and treatment of Rett syndrome using human induced pluripotent stem cells. Cell 143, 527-539. 
Marión, R.M., Strati, K., Li, H., Murga, M., Blanco, R., Ortega, S., Fernandez-Capetillo, O., Serrano, M., and Blasco, M.A. (2009). A p53-mediated DNA damage response limits reprogramming to ensure iPS cell genomic integrity. Nature 460, 1149-1153.

Masui, S., Nakatake, Y., Toyooka, Y., Shimosato, D., Yagi, R., Takahashi, K., Okochi, H., Okuda, A., Matoba, R., Sharov, A.A., et al. (2007). Pluripotency governed by Sox2 via regulation of Oct3/4 expression in mouse embryonic stem cells. Nat Cell Biol 9, 625-635.

Mayshar, Y., Ben-David, U., Lavon, N., Biancotti, J.C., Yakir, B., Clark, A.T., Plath, K., Lowry, W.E., and Benvenisty, N. (2010). Identification and classification of chromosomal aberrations in human induced pluripotent stem cells. Cell Stem Cell 7, 521-531.

Mitsui, K., Tokuzawa, Y., Itoh, H., Segawa, K., Murakami, M., Takahashi, K., Maruyama, M., Maeda, M., and Yamanaka, S. (2003). The homeoprotein Nanog is required for maintenance of pluripotency in mouse epiblast and ES cells. Cell 113, 631-642.

Moretti, A., Bellin, M., Welling, A., Jung, C.B., Lam, J.T., Bott-Flügel, L., Dorn, T., Goedel, A., Höhnke, C., Hofmann, F., et al. (2010). Patient-specific induced pluripotent stem-cell models for long-QT syndrome. N Engl J Med 363, 1397-1409.

Newman, M.A., Thomson, J.M., and Hammond, S.M. (2008). Lin-28 interaction with the Let-7 precursor loop mediates regulated microRNA processing. RNA 14, 1539-1549.

Nguyen, H.N., Byers, B., Cord, B., Shcheglovitov, A., Byrne, J., Gujar, P., Kee, K., Schüle, B., Dolmetsch, R.E., Langston, W., et al. (2011). LRRK2 mutant iPSC-derived DA neurons demonstrate increased susceptibility to oxidative stress. Cell Stem Cell 8, 267-280.

Niwa, H., Miyazaki, J., and Smith, A.G. (2000). Quantitative expression of Oct-3/4 defines differentiation, dedifferentiation or self-renewal of ES cells. Nat Genet 24, 372-376.

Okita, K., Ichisaka, T., and Yamanaka, S. (2007). Generation of germline-competent induced pluripotent stem cells. Nature 448, 313-317.

Park, I.H., Arora, N., Huo, H., Maherali, N., Ahfeldt, T., Shimamura, A., Lensch, M.W., Cowan, C., Hochedlinger, K., and Daley, G.Q. (2008a). Disease-specific induced pluripotent stem cells. Cell 134, 877-886.

Park, I.H., Zhao, R., West, J.A., Yabuuchi, A., Huo, H., Ince, T.A., Lerou, P.H., Lensch, M.W., and Daley, G.Q. (2008b). Reprogramming of human somatic cells to pluripotency with defined factors. Nature 451, 141-146.

Peng, S., Maihle, N.J., and Huang, Y. (2010). Pluripotency factors Lin28 and Oct4 identify a sub-population of stem cell-like cells in ovarian cancer. Oncogene 29, 2153-2159.

Pesce, M., and Schöler, H.R. (2001). Oct-4: gatekeeper in the beginnings of mammalian development. Stem Cells 19, 271-278.

Pick, M., Stelzer, Y., Bar-Nur, O., Mayshar, Y., Eden, A., and Benvenisty, N. (2009). Clone- and gene-specific aberrations of parental imprinting in human induced pluripotent stem cells. Stem Cells 27, 2686-2690.

Piestun, D., Kochupurakkal, B.S., Jacob-Hirsch, J., Zeligson, S., Koudritsky, M., Domany, E., Amariglio, N., Rechavi, G., and Givol, D. (2006). Nanog transforms NIH3T3 cells and targets cell-type restricted genes. Biochem Biophys Res Commun 343, 279-285.

Polo, J.M., Liu, S., Figueroa, M.E., Kulalert, W., Eminli, S., Tan, K.Y., Apostolou, E., Stadtfeld, M., Li, Y., Shioda, T., et al. (2010). Cell type of origin influences the molecular and functional properties of mouse induced pluripotent stem cells. Nat Biotechnol 28, 848-855

Rowland, B.D., and Peeper, D.S. (2006). KLF4, p21 and context-dependent opposing forces in cancer. Nat Rev Cancer 6, 11-23.

Sarig, R., Rivlin, N., Brosh, R., Bornstein, C., Kamer, I., Ezra, O., Molchadsky, A., Goldfinger, N., Brenner, O., and Rotter, V. (2010). Mutant p53 facilitates somatic cell reprogramming and augments the malignant potential of reprogrammed cells. J Exp Med 207, 2127-2140.

Shi, Y., Desponts, C., Do, J.T., Hahm, H.S., Schöler, H.R., and Ding, S. (2008). Induction of pluripotent stem cells from mouse embryonic fibroblasts by Oct4 and Klf4 with small-molecule compounds. Cell Stem Cell 3, 568-574.

Song, H., Chung, S.K., and Xu, Y. (2010). Modeling disease in human ESCs using an efficient BAC-based homologous recombination system. Cell Stem Cell 6, 80-89.

Stadtfeld, M., Apostolou, E., Akutsu, H., Fukuda, A., Follett, P., Natesan, S., Kono, T., Shioda, T., and Hochedlinger, K. (2010). Aberrant silencing of imprinted genes on chromosome 12qF1 in mouse induced pluripotent stem cells. Nature 465, 175-181.

Stadtfeld, M., Brennand, K., and Hochedlinger, K. (2008). Reprogramming of pancreatic beta cells into induced pluripotent stem cells. Curr Biol 18, 890-894.

Takahashi, K., Tanabe, K., Ohnuki, M., Narita, M., Ichisaka, T., Tomoda, K., and Yamanaka, S. (2007). Induction of pluripotent stem cells from adult human fibroblasts by defined factors. Cell 131, 861-872.

Takahashi, K., and Yamanaka, S. (2006). Induction of pluripotent stem cells from mouse embryonic and adult fibroblast cultures by defined factors. Cell 126, 663-676.

Thomson, J.A., Itskovitz-Eldor, J., Shapiro, S.S., Waknitz, M.A., Swiergiel, J.J., Marshall, V.S., and Jones, J.M. (1998). Embryonic stem cell lines derived from human blastocysts. Science 282 , 1145-1147.

Tiscornia, G., Vivas, E.L., and Belmonte, J.C. (2011). Diseases in a dish: modeling human genetic disorders using induced pluripotent cells. Nat Med 17, 1570-1576.

Tong, M., Lv, Z., Liu, L., Zhu, H., Zheng, Q.Y., Zhao, X.Y., Li, W., Wu, Y.B., Zhang, H.J., Wu, H.J., et al. (2011). Mice generated from tetraploid complementation competent iPS cells show similar developmental features as those from ES cells but are prone to tumorigenesis. Cell Res 21, 1634-1637.

Utikal, J., Maherali, N., Kulalert, W., and Hochedlinger, K. (2009a). Sox2 is dispensable for the reprogramming of melanocytes and melanoma cells into induced pluripotent stem cells. J Cell Sci 122, 3502-3510.

Utikal, J., Polo, J.M., Stadtfeld, M., Maherali, N., Kulalert, W., Walsh, R.M., Khalil, A., Rheinwald, J.G., and Hochedlinger, K. (2009b). Immortalization eliminates a roadblock during cellular reprogramming into iPS cells. Nature 460, 1145-1148

Viswanathan, S.R., Daley, G.Q., and Gregory, R.I. (2008). Selective blockade of microRNA processing by Lin28. Science 320 , 97-100.

Viswanathan, S.R., Powers, J.T., Einhorn, W., Hoshida, Y., Ng, T.L., Toffanin, S., O'Sullivan, M., Lu, J., Phillips, L.A., Lockhart, V.L., et al. (2009). Lin28 promotes transformation and is associated with 
advanced human malignancies. Nat Genet 41, 843-848.

Wu, Y., Zhang, Y., Mishra, A., Tardif, S.D., and Hornsby, P.J. (2010). Generation of induced pluripotent stem cells from newborn marmoset skin fibroblasts. Stem Cell Res 4, 180-188.

Yamanaka, S. (2007). Strategies and new developments in the generation of patient-specific pluripotent stem cells. Cell Stem Cell 1, 39-49.

Yazawa, M., Hsueh, B., Jia, X., Pasca, A.M., Bernstein, J.A., Hallmayer, J., and Dolmetsch, R.E. (2011). Using induced pluripotent stem cells to investigate cardiac phenotypes in Timothy syndrome. Nature 471, 230-234.

Yu, J., Vodyanik, M.A., Smuga-Otto, K., Antosiewicz-Bourget, J., Frane, J.L., Tian, S., Nie, J., Jonsdottir, G.A., Ruotti, V., Stewart, $R$., et al. (2007). Induced pluripotent stem cell lines derived from human somatic cells. Science 318, 1917-1920.

Yuan, X., Wan, H., Zhao, X., Zhu, S., Zhou, Q., and Ding, S. (2011). Combined chemical treatment enables Oct4-induced reprogramming from mouse embryonic fibroblasts. Stem Cells 29, 549-553.

Zhang, J., Lian, Q., Zhu, G., Zhou, F., Sui, L., Tan, C., Mutalif, R.A.,
Navasankari, R., Zhang, Y., Tse, H.F., et al. (2011). A human iPSC model of Hutchinson Gilford Progeria reveals vascular smooth muscle and mesenchymal stem cell defects. Cell Stem Cell 8, 31-45.

Zhao, T., and Xu, Y. (2010). p53 and stem cells: new developments and new concerns. Trends Cell Biol 20, 170-175.

Zhao, T., Zhang, Z.N., Rong, Z., and Xu, Y. (2011). Immunogenicity of induced pluripotent stem cells. Nature 474, 212-215.

Zhao, X.Y., Li, W., Lv, Z., Liu, L., Tong, M., Hai, T., Hao, J., Guo, C.L., Ma, Q.W., Wang, L., et al. (2009). iPS cells produce viable mice through tetraploid complementation. Nature 461, 86-90.

Zhao, Y., Yin, X., Qin, H., Zhu, F., Liu, H., Yang, W., Zhang, Q., Xiang, C., Hou, P., Song, Z., et al. (2008). Two supporting factors greatly improve the efficiency of human iPSC generation. Cell Stem Cell 3, 475-479.

Zhu, S., Li, W., Zhou, H., Wei, W., Ambasudhan, R., Lin, T., Kim, J., Zhang, K., and Ding, S. (2010). Reprogramming of human primary somatic cells by OCT4 and chemical compounds. Cell Stem Cell 7, 651-655. 